\title{
SPANNING THE GAP IN HUMAN CAPITAL MANAGEMENT PHILOSOPHY OF THE FIRMS - SIMPLIFIED GENERAL REFLECTIONS
}

\author{
NIRALI PANDIT \\ Post-doctoral Fellow, ICSSR at B.K. School of Professional and Management Studies, Gujarat University, India
}

\begin{abstract}
The current research on human capital management in firms revolves around identifying certain questions that seek answers to what is the actual philosophy behind human resource management (HRM) and how is this philosophy different from that of human capital management (HCM). If HCM is different from HRM, then how, and on what basis? Will firms benefit more if they upgrade to HCM from HRM or is it just a mindset of leaders that make them manage the firm either through HCM practices or through HRM practices? Further, looking at a more optimistic and spiritual meaning of HCM, do firms want to believe that they adopt and follow human capital management (HCM) practices rather than controlled ones or do they really have a mixed approached to run their organization? If the firm has more of a commitment-based philosophy rather than control-based philosophy, then the value addition will be different. But if not, then there is a need to figure out the purpose for improvising or developing the current practices so that there is value creation for value addition.

So, depending on the basic ideology of the firm (leader), the guiding principles of defining business practices are framed. Therefore, an attempt to study HRM systems and processes from human capital management perspective is needed. Right from entry of an employee to exit, how processes in existing HR functions, guides human capital to add value to the organization needs to be found.

This concept has been deliberated in detail in the following section. The discussion begins with philosophy or guiding principles of human resource management practices and human capital management practices. Based on this, there is an attempt to differentiate between the two. It follows with understanding the HR value chain and then measurement framework of human capital management in terms of systematically understanding the value of people and how value creation leads to value addition in organizations.

KEYWORDS: Management Philosophy, Human Relations Philosophy, Human Capital Management, Measurement
\end{abstract}

Received: Aug 09, 2020; Accepted: Aug 29, 2020; Published: Sep 21, 2020; Paper Id.: IJHRMRAUG20208

\section{PHILOSOPHY AND MEANING OF HRM}

In history, the evolution of organizational forms and managerial philosophies has happened together. It is nowadays referred as "the human relations philosophy" or "human relations model," for example, emerged along with the evolution of the large, vertically integrated functional organizations. Therefore, around World War - I, firms were guided by philosophy that supported the creation and management of the stable and loyal work forces these organizations needed. Later, post-World War II period, studies in organizational behaviour contributed to a "human resources philosophy". And from 1980s onwards, perspective of people management in organizations shifted dramatically in the western world, i.e. from personnel to human resource management (also called the HRM 
philosophy).

An HR philosophy of the firm characterizes the general beliefs and overriding principles (Becker \& Gerhart, 1996; Wright, 1998) towards its human resource management. Based on RBV theory, Boxall (1996) theorises that HRM can lay the foundation for competitive advantage (Hoskisson, Hitt, Wan, \& Yiu, 1999) by hiring and developing talented staff (Dunford et al., 2001) and melding their contributions with other resources within the firm to create synergy. But, the developed countries are witnessing the new HRM practices to be more associated with the emerging neoliberal economic and societal policies and practices (Peltonen/Vaara, 2012). "The effect of the neoliberal creed (laissez faire and free market capitalism) has led to increased work escalation, higher role demands, demands for lengthy working hours and increased performance, rise of pay for performance and enlarged investments in developmental activities and training. But, unfortunately, this philosophy resulted in lowered job security and increased peer level competition (e.g., Hassard et al. 2007; Peltonen/Vaara 2012). While, for Market-focussed HRM philosophy, Lawler and Boudreau (2012), argue that the HRM function must think about whether the elements of its design indeed create a high-performance organization. The implementation of HRM principles (with more focus towards market), which began concurrently with the adoption of neoliberal free-market principles at the beginning of 1990s, drove firms to adopt and implement the well-established highperformance HRM practices of developed countries. Later, a 'soft' and a 'hard' approach (McDonnell and Burgess, 2013) to HRM principles were introduced where 'soft' HRM practices focused on maintaining employee engagement and commitment, comprise strong communications, employee motivation, training and redeployment of employees. On the other hand, 'hard' HRM method comprised of crisis-driven layoffs, recruitment freezes, lowered working hours, pay cuts, reductions in training and development, and exploitation of the weaker bargaining power of trade unions and employees. Thus, guiding principles of HRM and adoption of 'hard' approaches over 'soft' ones brought forth to managers the realization of the short-term loss of substantial amount of human capital and endangering long-term competitiveness" (Vokic et.al. 2018).

Schuler (1992) suggested that, "HR management is comprised of five underlying levels: philosophy, policies, programmes, practices, and processes". According to Schuler (1992), "a firm's HR philosophy reflects how the organization regards its human resources, what role the resources play in the overall success of the business, and how they are to be treated and managed. This statement is typically very general, thus allowing interpretation at more specific levels of action within an organization; HR policies are statements providing guidelines for action on people-oriented business issues related to strategic needs. HR programmes represent coordinated HR efforts that help implement strategic business needs, HR practices are used to elicit and reinforce needed behaviours by workers, and HR processes define how activities are to be carried out". This examination and study are critical to understand the usefulness human capital management systems (Schuler, 1992). Therefore, the researcher suggested that, "management of human resources should be comprised of five underlying levels that include philosophy, policies, programmes, practices, and processes". This past research insists that, "firm's HR philosophy reflects, how the organization regards its human resources, what role the resources play in the overall success of the business, and how they are to be treated and managed. This statement is typically very general, thus allowing interpretation at more specific levels of action within an organization" (Lepak et. al., 2004). Generally, business issues that are concerned with people and related to strategic needs can be sorted based on statements providing guidelines for action. Gradually, these guidelines become policy related to human resource in organizations. Programmes related to people denote synchronized HR efforts that help to meet strategic business goals. HR practices are helpful to support and underpin desired and wanted behaviours by employees. Finally, processes of human resource outline and 
explain the manner in which activities are to be carried out by employees. Thus, in order to understand the usefulness of people, it is critical to consider these levels of analysis.

According to Huselid, "human resource practices followed in organization are usually those that have an economically and statistically significant impact on both intermediate worker outcomes (turnover and productivity) and short- and long-term measures of corporate financial performance. But progressive human resource management practices, (including selectivity in staffing, training, and incentive compensation), are positively related to perceptual measures of firm performance. Employment security, selectivity in hiring/recruiting, high wages, incentive pay based on performance appraisal, employee ownership, information sharing, participation and empowerment, self-managed teams, training and skill development, job design, and promotion from within, reduced status distinction and barriers, measurement of HR practices and quality of work life were studied as HRM practices in organizations across the literature in diverse employee management related studies" (Huselid, 1995; Huselid \& Becker, 1995; Delery \& Doty, 1996; Becker \& Huselid, 1996; Hartog, 2004). These practices are built on HRM policy that is a reflection of an organization's philosophy, irrespective of the fact, whether they are commitment based or cost oriented.

It can be contended that a firm's philosophy related to the role and value of human capital plays an influential part in the final decisions that firms take related to method of managing their employees. It is rational that philosophy towards people the firm's overall strategic objectives (Huang and Liu, 2008). For example, Jackson et al., (2002) portrays the influence of strategy on HR philosophy asserting that, "organization seeking to gain competitive advantage through innovation [strategy] should be more likely to use personnel practices that cue and reinforce expertise, risk taking, and a long-term focus, in comparison with organization not interested in creating an atmosphere conducive to innovation." Similarly, Miles and Snow, (1980) also recommended that, "analyzers, prospectors, and defender firms differ substantially in the extent to which they follow a 'make' vs. 'buy' philosophy regarding the management of their employees". So, with different terminologies, these researchers assert that the firm strategy is likely to be associated with their overall people management philosophy. Similarly, “a firm's strategy is influenced by firm's broad objectives for employee management and the decisions made in line with HR philosophy" (Lepak et.al. 2004).

Lepak et al. (2004) contend that the relationship between HR and strategy is based on the premise that this relationship is influenced by expectation from employees to contribute toward that strategy. To be more precise, defined HR policies are impacted by expected contributions of employees. But such HR policies need to be appropriate enough for the strategic management of groups of employees such that they encourage explicit employee contributions. However, it the human resource philosophy of the firm that influences a precise choice of certain HR policies that are implemented at ground level. Stress on the explanations causing such practice, for example, desired employee contributions, surpass prominence on the selected human resource practices included in a firm's HR system. Therefore, essentially, there is a collection of HR policies that may be fit for different types of employee contributions instead of that one best HR system.

Thus, over the last century, philosophy in management of people at workplace has evolved or shifted from personnel to HRM and then to HCM. An orthodox, personnel management viewpoint treats people as disposable factor of production, is oriented towards cost minimization and has a short-term perspective (Bahtijarević-Šiber 1999). While employers who adopt and implement HRM philosophy look at people as the most profitable investment, long-term asset and a principal source of sustained competitive advantage (Wright et al. 1994; O'Reilly/Peffer 2000). Storey (1995) describes it as an approach shift from supervising to development. This can be seen in the fact that organizations nowadays 
have a compensation policy that is not awarded anymore based on job evaluation (fixed grades) but is performance-related, collective bargaining contracts have moved on to become individual contracts, controlled and single-sided flow of communication is now an increased one, division of labour has become teamwork, and restricted access to learning material and knowledge is replaced by learning organizations). Literature witnesses that HRM perspective to people management transited to HCM perspective with a blurred view towards progressive employee management philosophy that can be seen in strategic human resource management literature (Guthrie et al., 2002). "This strategic human resource management (SHRM) literature has focused on the importance of employee empowerment-oriented human resource management principles and practices (also interchangeably denoted as 'high involvement work systems', 'commitmentoriented practices', 'human capital-enhancing practices') that provide employees at middle and lower levels the skills, information, and authority to make decisions at the workplace" (e.g. Datta et al., 2005; Guthrie et al., 2002). However, when HRM philosophy and firm performance started being mediated with innovation for developing competitive advantage (Porter, 1980), the philosophy of human capital replaced previous ones in the management of people (Selvarajan et. al., 2007). Thus, HCM perspective shifted from nurturing people to investing in people. Human capital philosophy identifies human capital as individuals that are talented, trained, and experienced (human capital), and runs on the belief that they are different from organizational capabilities that also encompass relationships among individuals, organizational structure, culture and patterns of interactions among individuals, (i.e. social capital) (Barney, 1997, Becker, 2002).

\section{MEANING AND PHILOSOPHY OF HCM}

Companies would want to attract the best human resource, but in pursuit of shape and control, it crushes the human quality. Then that residue is barely a resource. "Talent, commitment, integrity and all the other qualities sought in employees emerge from the uniquely human spirit, from the whole person. But the organizational penchant for rewarding compliance and punishing dissent leads to an alienated managerial cadre. So, some talent will flee and that which stays to be moulded will have a quality deserved by the organization. Authentic people may join an organization but they never belong to it if they're simply expected to merely comply rather than contribute." Many organizations confuse high performers with human capital. But the question is - are high performers human capital, or are high potentials, human capital. Researchers also use the term talent and human capital interchangeably.

The meaning has its roots in the literature of economics (Becker, 1996). It is neither physical capital nor financial capital. In fact, Becker has defined this capital as "the knowledge, skill, creativity, and health of the individual" (Becker, 2002). Human capital plays an imperative role in development of people, improving their earning and lifestyle, improving knowledge, skill, and product capacities, economic growth and reducing poverty. The accumulation of knowledge and human capital has a direct effect on efficiency (Carmeli \& Schaubroeck, 2005). According to Pasban and Nojedeh, "If this is the guiding philosophy of a firm, then, how human capital leads to more efficiency and revenue needs to be seen. Since employees and individuals have applied human capital to their job, they receive their investment reward from human capital through salary, benefits, job satisfaction, and more learning opportunities as well as promotion. These achievements allow families and governments to invest a large part of their resources in education and training human force. It is worth mentioning that economic attitude towards human capital (education and training labour force) is vital for country's efficiency and economic success"

But now, with the changing business environment, most firms have come up with a new structure (delayed, highly flexible, and controlled by market mechanisms rather than administrative procedures) aligned thyself on such a value chain 
that according to their main competencies, obtaining sponsored resources through the process of outsourcing and strategical alliance. So, managing such kinds of organizations in the $21^{\text {st }}$ century demands a need from managers to apply a new update of management - "human investment model", one that fits this emerging structure of network organizations. This human investment philosophy in action, shows how managers are making investment in competence and trust building at the individual, team, firm and network levels.

According to Stiles and Kulvisaechana, "The organizations' emphasis on human capital is based on the view that the market value of organizations depends more on intangible assets (human capital), therefore, organizations must raise the level of organizational learning, increase the level of employees' skills and abilities through encouraging them, and provide an atmosphere where knowledge is created, shared and applied and learning becomes a habit" (Stiles \& Kulvisaechana, 2003).

In opinion of Miles and Snow "Ideally, the success of any form of organization requires that companies be able to deftly manage their internal resources to form autonomous operating units and self-managing teams, eliminate unneeded administrative mechanisms, and empower everyone to act as an entrepreneur and leader. Externally, companies require being adept at relationship management, and willing to make both hard and soft investments in their partners (not only financial but also investments in competence and trust building). But this requires a firm's philosophy in which employees act as partners in their own development. Managers in turn must not only facilitate employee development, but also locate opportunities for employees to apply their continuously expanding knowledge and ability. Such a philosophy is called the "human investment model" that legitimates and promotes the creation of proactive competence needed by organizations in today's business environment."

Thus, human capital management ( $\mathrm{HCM})$ is a complete set of practices for employee related activities that include recruitment of employees, management of employees, developing and optimizing the present employees of a firm. The HCM terminology implies a method to human resource management (HRM) that looks at employees with a partnership view, assets that can be invested in and viewed as long-term capital. Human capital management is imperative for making the business successful because recent workforce trends and employment and employee laws add more complexity to recruitment, retention, legislative compliance and employee management. And in today's workplace, success in employee management requires that leaders or HR managers of the organization act proactively rather than reactively. Current workplace trends like changing demographics, an upsurge of gig economy, rise in remote workforce, and inclusion of intangible assets in business investment, complex legislation and big HR data makes HCM a need for an hour. In most business organizations, HCM practices are streamlined. The organization with proactive HCM practices removes the tendency of HR silos and implements a proper payroll system and timekeeping processes with an objective of achieving a positive return on investment.

HCM has come to be nearly synonymous with the human resources function in some organizations. Therefore, firms strongly need to introspect their own guiding principles to meet firm strategy.

\section{HCM OR HRM - A CHOICE OR A STRATEGY?}

Leaders or key decision makers hold certain ideologies or philosophies related to the relative role and value of employees (Child, 1997). Such decisions culminate into choices of managers related to human capital management. But it is still not necessary that the underlined HR philosophy of these key decision makers matches with business related strategic factors. 
For example, organizations that lay emphasis on competition that is based on cost, may stick to an HR philosophy where it underlying principle is that employees are viewed as a cost to minimise (control-oriented). However, the same firms, with cost-perspective, might also stick to a more people-oriented HR philosophy which promotes an increase in efficiency and productivity among employees. This might result in even higher outcomes as compared to results of firms that indulge in higher levels of employee investment and empowerment just to encourage employees to work smarter. Thus, key decision makers might tend to choose specific human resource policies to convey their significant values and beliefs to employees and managers (Schuler, 1992), thus making this policy either a resource-oriented policy or a capital-oriented policy.

All in all, this means that firms operating under the guiding principles of resource-based philosophy and at the same time giving a lot of importance to long-term commitment toward employees, would be more in range with the guiding principles that lay emphasis on employee performance and development (Delery and Doty, 1996). However, in their business policy archives, they may not very evidently name it as a human capital policy. On the other hand, firms that implement employee policies based on control-oriented guiding principles with a focus on maximising efficiency and standardisation (Arthur, 1992). In either case, it is the underlying values or guiding principles of leaders that play an essential role in decisions related to the people management in organizations.

Organization that consider an investment perspective in HRM policy are believed to include HCM functions in the category of core HR, talent management, workforce management and service delivery. Firms with investment philosophy include benefits administration, maintenance of employee data and records, payroll, on-boarding and compliance management towards their core human resource activities. Towards an effort of talent management, they implement process of recruiting in a collective way, develop and retain employees through recruitment, exercise performance management, compensation management, learning and also have a clear and transparent succession planning. With an objective of investment-oriented workforce management, such firms include time and attendance management, workforce planning, labour scheduling and budgeting in their planning and management of workforce. Firms with HCM orientation also pay attention to service delivery with the help of HR help desks, intranet portals, employee self-service and manager self-service. Thus, unlike human resource management, human capital management functions typically have technological systems affect mostly all functional areas, especially analytics, social media, collaborating partnership and teamwork, and employee engagement.

Both capital and cost perspectives reflect the value of need for multi-levelled analysis in HR (Becker and Gerhart 1996 and Schuler 1992). For instance, on one hand there would be employee policies that are optimal to stimulate risk taking and innovation while on the other hand, certain HR policies might boost loyalty and organisational commitment. Therefore, there is a need to find where firms implement HCM perspective and where they carry on with HRM perspective in their daily practices for a smooth functioning of system for meeting firm strategy.

Software solutions companies that offer HCM solutions separate it from that of HRM solutions. These companies have HCM solutions where they typically include human resource information system capabilities and features, employee performance and goal tracking. They mostly cover on-boarding, analytics, position control and salary planning, access to company databases, policies and procedures. Their people solutions also have documentation and data and global capabilities that include features such as multi-lingual, multi-currency and country-specific formatting. While their human resource management solutions, only include time and labour management along with features and capabilities. Companies that adopt human capital management suits do not include current cost management aspects like time and labour 
management. Maybe, in technological terms, features of both, human capital management and human resource management are increasingly blurred. Most of the times, the terms used may also be interchangeable. This is because, both the systems use cloud computing, databases and other elements to handle workforce management. But according to Norton, "co-developer of the balanced scorecard, the greatest anxiety today for business executives in the new economy is that, "human capital is the foundation of value creation" and they don't know how to create, measure, keep it or ultimately value it" (Becker, Huselid \& Ulrich, 2001).

Though, architecture (Kellner et al., 2016) of the system of the firm represents the guiding principles of the HR system (Becker and Gerhart, 1996), it is basically the system itself that refers to the policy and practices. For instance, it may be the choice of the firms to value the performance of an employee or may strive to control and monitor activity of employee. At this level, the HR system refers to an overall philosophy rather than any particular policy, practice, or bundle of HR practices. Irrespective of philosophy, effective management demands measure to guide it. And this measurement framework will need to identify the value of people. This demands human capital management practices to be broken down into activities or tasks of human capital and to be able to identify its possible measurement. For example, the activity of employing new forces can be possibly measured with aspects such as cost that can be incurred, time budget, number of people required, quality and compatibility with strategic criteria and the like.

\section{MEASURING HUMAN CAPITAL / HUMAN CAPITAL PHILOSOPHY}

Barney (1991) suggests that "sustainable competitive advantage can be created with the help of resource that have value (external environment usefulness), rareness (unique resource), imperfect inimitability (not easily copied), and nonsubstitutability" (cannot be replaced by other products/services or firms). Thus, these four features become imperative while measuring efficiency and effectiveness of human capital.

Selvarajan et al. (2007) “measured the firm's human capital philosophy using a scale adapted from Guest and Peccei (2001). The five items used in this study tapped into the following aspects of a firm's human capital philosophy: reward sharing, competencies development, feedback from employees, enhancing employees' employability and information sharing. They used a five-point Likert-type scale that asked the top management to rate their firm's philosophy."

The study of the importance of human capital in the firm and the attributes of human capital suggest that the common index, which is imperative at all levels of management in the organization, is human skill. The members who work in the central core of the organization must develop higher skills. These people must have the required knowledge, information, innovation, and creativity to increase the satisfaction of customer and create competitive advantage for the organization.

Many researchers have also referred to high performer human capital or high potential human capital while conducting efficiency studies for value creation and value addition (Barney 1991; Murphy 2007). For example, a positive correlation between of high performance work systems and performance of the firm (Huselid, 1995) include "extensive recruitment, selection, and training procedures; formal information sharing, attitude assessment, job design, grievance procedures, and labour-management participation programs; and performance appraisal, promotion, and incentive compensation systems that recognize and reward employee merit have all been widely linked with valued firm-level outcomes". 
Researchers believe that some organizational theorists put the rules of human capital theory to support the ability to create useful competitions between firms by means of development of individual human resources. And for this purpose, it is imperative to develop human capital (Pasban and Nojedeh, 2016) in organizations where people are equipped with features such as creativity and innovation (Daft, 1998), knowledge and skill (Nonaka \& Reinmoeller, 2000; Teece, 2000; Nerdrum and Erikson 2001), value added (Armstrong, 2008), competitive advantage (Armstrong, 2008) and improving the satisfaction of customer from the organization (Gonzalez \& Garazo, 2006). This means that the individuals must have required knowledge, information, innovation, and creativity to increase the customer's satisfaction and create competitive advantage for the organization. Seemingly, it is not as straightforward as it sounds. To fulfil this purpose, organizations need to create value driven roles, identify who can be value creators (knowledge, skills, experience, other) for those particular roles and nurture value generators. The firm should also know to distinguish value creators and value generators from others and have or develop methods to engage and retain them. However, most researchers are related to how human capital (with its typical features) can contribute to firm efficiency, effectiveness and competitive advantage. But there is a need to check how firms (based on their philosophy) bring these outcomes by adopting and following HCM practices. Further, which practice or activity adds value and which does not. If value addition through value creation is the guiding principle of HCM philosophy, then, this calls upon dividing prevailing HRM/HCM activities into task and practices and identifying how these activities generate value addition and lead to organizational goals. Since the goal of capital is more to do with returns, there is a need to identify whether the present HR activities followed in the firm are able to give returns or not? Further, if yes, then whether they are long term or short term. And lastly, since the philosophy of human capital management is based on the guiding principles of efficiency (value addition) and effectiveness (firm outcomes), the HR activities being practiced in the firm can be studied from these two points of view. For example, whether HR activities that might include planning of workforce, recruitment and selection, compensation and benefits, industrial relations, training, internal mobility, talent management, coaching, downsizing, organization design and such are efficient enough or not. But to check their efficiency, one needs to measure their effectiveness. If they are effective, they were efficient. Thus, effectiveness for efficiency can be measured through outcomes in the form of employee engagement, retention, absenteeism (sickness), competency levels, performance, workforce costs and talent metrics (Vulpen, 2018).

Alone efficiency metrics typically include "cost of hire, time to hire/time to fill, learning and development budget, training time in days, time since last promotion and the like. The main focus here is cost savings, reached by optimizing these efficiency metrics. If they are effective, it is because they were efficient. But if they are efficient, they are not necessarily effective. Here lies the difference in the philosophy of the organization related to HR department. For example, if they can lower the cost of hire while keeping the time to hire metric stable, they are more efficient. This immediately shows the big weakness of these organizations that focus on reducing HR cost - and thus approach HR as a cost-centre instead of focusing on the value that HR adds. In other words, HR efficiency says nothing about how HR contributes to the business." Therefore, it is necessary to check effectiveness when one wants to know the value addition or outcome of an activity.

Effectiveness metrics typically include engagement, retention/employee turnover, absenteeism rate, individual performance, team performance and quality of hire.

All these metrics provide details related to the performance of the workforce. For example, when engagement is high, HR is more effective than when engagement is low. The same holds true for retention and (inversely) for employee 
absence. Effectiveness is how well the intended HR practices are executed by managers. Thus, the human capital management approach leads an organization to be more efficient (high on human capital), more effective (high on human as well as social capital) and thus have positive organizational outcomes (high organizational capital) in the form of market share, profit margins, market capitalization, customer satisfaction and customer loyalty. These are the kind of outcomes that add value to the business and make the business more viable in the long term. Thus, to find out whether organizations are following HCM practices or not, it can be analysed based on value addition that each activity of employee management makes in its HR value chain.

The philosophy of human capital has also been studied from the viewpoint of the theory of "partnership" (Guest and Peccei, 2001). Partnership between employees and employers can also be in the form of participating directly and a psychic state approach. It is based on a repetitive mutual theme, the idea of focussing on the common interests and goals of interdependent parties while recognising that the potential interests are very different. Role of principles, policies and practices of the organization is eminent for promoting this mutual benefit and outcomes of mutuality (Donaldson and Preston, 1995).

There is a need to receive validation by recognising principles, practices and outcomes that claim to practice human capital management practices along with the practices that endorse any underlying pattern(s) that enables to identify the essence of human capital management in organizations.

Thus, one objective is to recognise those principles and practices that may be related to human capital management. And to check how they differ among those firms that report their progress related to human capital management.

Another objective is to check whether this progress of human capital management approach is related to outcomes of value (creation and addition) to the parties involved.

To analyse this premise, fields of human resource management practices and corporate performance (Becker and Gerhart, 1996) will be reviewed.

\section{CONCLUDING REMARKS}

While analysing principles and beliefs, analysis of organizational culture will help to analyse vision, mission statement, employment relation policy and strategy. These are likely to reflect the principles that the organization endorses. It will help to identify the normative beliefs about human capital among the dominant promoters or key policy makers in the organization. These principles can also be written as agreed rules or underlying statement of intent (Cutcher-Gershenfeld and Verma, 1994). These principles have to be recognized and agreed upon by both management and employees. Which means, organizations that claim making progress towards principles of human capital management, would report stronger endorsement of some or all principles associated with different approaches to human capital management.

A core assumption is that human capital management approach will benefit the organization as well as the employees. According to Rousseau \& guest, “Benefit for the organization can be in the form of higher employee commitment to the organization, lower levels of absence, labour turnover and industrial conflict, and superior performance based on a range of internal and external criteria. Provisional support for this argument can be found in the literature (include references). While from employee perspective, the benefits of HCM principles might be expected to include 
opportunities to exercise greater autonomy and direct participation (Batt and Applebaum, 1995); a more positive psychological contract and an opportunity to gain on human capital criteria thus increasing one's own employability and overall competitiveness.” (Rousseau 1995; Guest, 2000)

The basic premise is there is a link between philosophy, practice and outcomes. It is imperative to reinforce practices that are underpinned by the guiding principles, which are supported by policy-makers and senior management in the organization (Cutcher-Gershenfeld and Verma, 1994). Therefore, based on literature review of HRM (Becker and Gerhart, 1996), analysis of link between philosophy (strategy), practice and outcomes is required. The study can be done by extending the analysis to examining the impact of human capital management practices on employee and management outcomes in the HR value chain. The idea for this is that implementation of HCM principles and practices will improvise the perspective of more positive psychological contract among the workforce and will also enhance their influence about work-related important wider decisions, over higher commitment, higher extra-role contributions and thus, higher engagement. It will also result in lesser levels of turnover, absence and conflict. Such positive intermediate outcomes will be a result of having a direct and indirect impact on productivity, quality, innovation, sales and financial outcomes (Delaney and Huselid, 1996).

\section{REFERENCES}

1. Armstrong, M. (2008). Strategic human resource management (4th ed.). London, UK: Kogan http://103.5.132.213:8080/jspui/bitstream/123456789/1074/1/Armstrong_SHRM_Action.pdf

2. Arthur, J.B. (1994). 'Effects of human resource systems on manufacturing performance and turnover'. Academy of Management Journal, 37: 3, 670-687

3. https://www.jstor.org/stable/256705?seq=1\#metadata_info_tab_contents

4. Bahtijarević-Šiber, F. (1999): Human resource management [in Croatian]. Zagreb: Golden marketing.

5. $\quad$ https://pdfs.semanticscholar.org/9ad3/c6500d35af84917d00c57b7beb79ecedad3c.pdf

6. Barney, J.B. (1991). 'Firm resources and sustained competitive advantage'. Journal of Management, 17: 1, 99-120

7. $\quad$ https://doi.org/10.1177/014920639101700108

8. Batt, R. and Applebaum, E. (1995). 'Worker participation in diverse settings: does form affect the outcome, and if so, who benefits?' British Journal of Industrial Relations, 33: 353-78.

9. https://digitalcommons.ilr.cornell.edu/cgi/viewcontent.cgi? article $=1195 \&$ context $=$ cahrswp

10. Becker, G.S. (2002) The age of human capital. In: LAZEAR, E.P. (ed.) Education in the twenty-first century. Palo Alto, CA: Hoover Institution Press, pp3-8.

11. https://www.hoover.org/sites/default/files/uploads/documents/0817928928_3.pdf

12. Becker, B.E. and Gerhart, B. (1996). 'The impact of human resource management on organizational performance: progress and prospects'. Academy of Management Journal, 39: 4, 779-801

13. https://www.jstor.org/stable/256712?seq=1\#metadata_info_tab_contents

14. Boxal l, P. (1996). 'The strategic HRM debate and the resource based view of the firm', Human Resource Management Journal, 6 (3), pp. 59-75 
15. https://doi.org/10.1111/j.1748-8583.1996.tb00412.x

16. Cutcher-Gershenfeld J. and Verma, A. (1994). 'Joint Governance in North American workplaces'. Internaltional Journal of Human Resource Management, 5: 547-80

17. Carmeli, A., \& Schaubroeck, J. (2005). How leveraging human resource capital with its competitive distinctiveness enhances the performance of commercial and public organizations. Human Resource Management, 44(4), 391-412

18. . https://doi.org/10.1002/hrm.20081

19. PEDDIKAYIL, SIDDIQUE KADAVATHE, and A. ABBAS MANTHIRI. "MAKING HUMAN CAPITAL A SOURCE OF COMPETITIVE ADVANTAGE FOR EDUCATIONAL INSTITUTIONS." International Journal of Human Resource Management and Research (IJHRMR) ISSN (P): 2249-6874; ISSN (E): 2249-7986 Vol. 8, Issue 2, Apr 2018, 19-26

20. Child, J. (1997). Strategic Choice in the Analysis of Action, Structure, Organizations and Environment: Retrospect and Prospect. Organization Studies, 18(1), 43

21. https://doi.org/10.1177/017084069701800104

22. Datta, Deepak \& Guthrie, James. (2005). Human Resource Management and Labor Productivity: Does Industry Matter?. Academy of Management Journal. 48. 10.5465/AMJ.2005.15993158.

23. https://www.researchgate.net/publication/254398906_Human_Resource_Management_and_Labor_Productivity_Does_Indust ry_Matter

24. KALUVA, MAHESH, and PUSHPA SRI DEGALA. "A THEORETICAL PERSPECTIVE OF THE IMPORTANCE OF STRATEGIC HUMAN RESOURCE MANAGEMENT IN THE 21 ST CENTURY." International Journal of Human Resource Management and Research (IJHRMR) ISSN (P): 2249-6874; ISSN (E): 2249-7986 Vol. 9, Issue 1, Feb 2019, 1-10

25. Huselid, M. (1995). 'The impact of human resource management practices on turnover, productivity, and corporate financial performance'. Academy of Management Journal, 38: 3, 635-672

26. https://www.markhuselid.com/pdfs/articles/1995 AMJ HPWS Paper.pdf

27. Delery, J.E. and Doty, D. (1996). 'Modes of theorizing in strategic human resource management: tests of universalistic, contingency and configurational performance predictions'. Academy of Management Journal, 39: 4, 802-835Donaldson and Preston, 1995

28. https://doi.org/10.5465/256713

29. Lakshmi, P., and P. Pratap. "HR analytics-a strategic approach to HR effectiveness." International Journal of Human Resource Management and Research 6.3 (2016): 21-28.

30. Fodor, Peter \& Poór, József. (2009). HRM and Knowledge Management in Light of the Present Economic and Financial Crisis in Hungary - Empirical Research 2008-2009.

31. https://www.researchgate.net/publication/238107680_HRM_and_Knowledge_Management_in_Light_of_the_Present_Econo mic_and_Financial_Crisis_in_Hungary_-_Empirical_Research_2008-2009

32. Varela, José \& Garazo, Teresa. (2006). Structural Relationships between Organizational Service Orientation, Contact Employee Job Satisfaction and Citizenship Behavior. International Journal of Service Industry Management. 17. 23-50. 10.1108/09564230610651561.

33. https://www.researchgate.net/publication/235295752_Structural_Relationships_between_Organizational_Service_Orientation 
Contact Employee Job Satisfaction and Citizenship Behavior

34. Madhavi Lakshmi, P., and P. Siva Pratap. "HR Analytics-a Strategic Approach to HR Effectiveness." International Journal of Human Resource Management and Research (IJHRMR) ISSN (P) (2016): 2249-6874.

35. Guest, David \& Peccei, Riccardo. (2001). Partnership at Work: Mutuality and the Balance of Advantage. British Journal of Industrial Relations. 39. 207-236. 10.1111/1467-8543.00197.

36. https://www.researchgate.net/publication/4988714_Partnership_at_Work_Mutuality_and_the_Balance_of_Advantage

37. Den Hartog, Deanne \& Boselie, Paul \& Paauwe, Jaap. (2004). Performance Management: A Model and Research Agenda. Erasmus Research Institute of Management (ERIM), ERIM is the joint research institute of the Rotterdam School of Management, Erasmus University and the Erasmus School of Economics (ESE) at Erasmus Uni, Research Paper. 53. 10.1111/j.1464-0597.2004.00188.x.

38. https://www.researchgate.net/publication/4752495_Performance_Management_A_Model_and_Research_Agenda

39. Huselid, Mark. (1995). The Impact of Human Resource Management Practices on Turnover and Productivity. The Academy of Management Journal. 38. 10.2307/256741.

40. https://www.researchgate.net/publication/228215412_The_Impact_of_Human_Resource_Management_Practices_on_Turnove $\underline{r \text { and_Productivity }}$

41. Huselid, Mark \& Becker, Brian. (1995). The strategic impact of high performance work systems.

42. https://www.researchgate.net/publication/228589016 The strategic impact of high performance work systems

43. Chow, Irene \& Huang, Jia-Chi \& Liu, Shanshi. (2008). Strategic HRM in China: Configurations and competitive advantage. Human Resource Management. 47. 687 - 706. 10.1002/hrm.20240.

44. https://www.researchgate.net/publication/227640434 Strategic HRM in China Configurations and competitive advantage

45. Lepak, D.P., Marrone, J.A. and Takeuchi, R. (2004) 'The relativity of HR systems: conceptualising the impact of desired employee contributions and HR philosophy', Int. J. Technology Management, Vol. 27, Nos. 6/7, pp.639-655.

46. http://citeseerx.ist.psu.edu/viewdoc/download?doi=10.1.1.892.2285\&rep=rep $1 \&$ type $=p d f$

47. Mcdonnell, Anthony \& Burgess, John. (2013). The impact of the global financial crisis on managing employees. International Journal of Manpower. 34. 10.1108/IJM-04-2013-0076.

48. https://www.researchgate.net/publication/262900455_The_impact_of_the_global_financial_crisis_on_managing_employees

49. Nerdrum, Lars \& Erikson, Truls. (2001). Intellectual Capital: A Human Capital Perspective. Journal of Intellectual Capital. 2. 127-135. 10.1108/14691930110385919.

50. https://www.researchgate.net/publication/235302963_Intellectual_Capital_A_Human_Capital_Perspective

51. O'Reilly, Charles \& Pfeffer, Jeffrey. (2000). Hidden Value: How Great Companies Achieve Extraordinary Results with Ordinary People.

52. https://www.researchgate.net/publication/40942719_Hidden_Value_How_Great_Companies_Achieve_Extraordinary_Results _with_Ordinary_People

53. Pasban, Mohammad \& Nojedeh, Sadegheh. (2016). A Review of the Role of Human Capital in the Organization. Procedia Social and Behavioral Sciences. 230. 10.1016/j.sbspro.2016.09.032. 
54. https://www.researchgate.net/publication/308740770 A Review of the Role of Human Capital in the Organization

55. Peltokorpi, Vesa \& Vaara, Eero. (2012). Language Policies and Practices in Wholly Owned Foreign Subsidiaries: A Recontextualization Perspective. Journal of International Business Studies. 43. 808-833. 10.1057/jibs.2012.28.

56. https://www.researchgate.net/publication/234021804 Language Policies and Practices in Wholly Owned Foreign Subsid iaries A Recontextualization Perspective

57. T.T. Selvarajan, Nagarajan Ramamoorthy, Patrick C. Flood, James P. Guthrie, Sarah MacCurtain \& Wenchuan Liu (2007) The role of human capital philosophy in promoting firm innovativeness and performance: test of a causal model, The International Journal of Human Resource Management, 18:8, 1456-1470, DOI: 10.1080/09585190701502588

58. https://www.tandfonline.com/doi/abs/10.1080/09585190701502588

59. John Storey (ed.): Human Resource Management. A Critical Text: 1995, London, New York: Routledge. 399 pages. (1996). Organization Studies, 17(1), 158-158. https://doi.org/10.1177/017084069601700115

60. Van Vulpen P., Brinkkemper S., Jansen S., Lucassen G. (2018) Continuous Software Portfolio Performance Management. In: Wnuk K., Brinkkemper S. (eds) Software Business. ICSOB 2018. Lecture Notes in Business Information Processing, vol 336. Springer, Cham. https://doi.org/10.1007/978-3-030-04840-2_6

61. Wright, Patrick \& McMahan, Gary \& Mcwilliams, Abagail. (1994). Human Resources as a Source of Sustained Competitive Advantage. The International Journal of Human Resource Management. 5. 301-326.

62. https://www.researchgate.net/publication/234075755_Human_Resources_as_a_Source_of_Sustained_Competitive_Advantage

63. Becker, B. and Gerhart, B. (1996) 'The impact of human resource management on organizational performance: progress and prospects', Academy of Management Journal, Vol. 39, pp.779-801

64. Wright, P.M. and Snell, S.A. (1998) 'Toward a unifying framework for exploring fit and flexibility in strategic human resource management', Academy of Management Review, Vol. 23, pp.756-772

65. Hoskisson, R. E., Hitt, M. A., Wan, W. P., Yiu, D. (1999). Theory and research in strategic management: Swings of a pendulum. Strategic Management Journal, 25 (3), 417-456.

66. Dunford, B. B., Snell, S. A. \& Wright, P. M.(2001). Human resources and the resource-based view of the firm, (CAHRS Working Paper \#01-03). Ithaca, NY: Cornell University, School of Industrial and Labor Relations, Center for Advanced Human Resource Studies. http://digitalcommons.ilr.cornell.edu/cahrswp/66

67. Schuler, R.S. (1992) 'Strategic human resource management: linking people with the needs of the business', Organizational Dynamics, Vol. 20, pp.19-32

68. Boxall, P. F. (1996). The Strategic HRM Debate and the Resource-based View of the Firm. Human Resource Management Journal, 6(3), 59-75.

69. Boxall, P. F. (1998). Human resource strategy and industry-based competition: A conceptual framework and agenda for theoretical development. In P.M. Wright, L.D. Dyer, J.W. Boudreau, \& G. T. Milkovich (Eds.) Research in Personnel and Human Resources Management (Supplement 4, pp. 1-29). Madison, WI: IRRA.

70. Vokic, Nina Poloski; Klindzic, Maja; Hernaus, Tomislav (2018). Changing HRM Practices in Croatia: Demystifying the Impact of the HRM Philosophy, the Global Financial Crisis and the EU Membership, Journal of East European Management Studies, Vol 23, No 2 
71. Jackson, Susan \& Schuler, Randall. (2002). Managing individual performance: A strategic perspective. In book: Psychological Management of Individual Performance (pp.372-390). Edition 1, chapter 18, John Wiley \& Sons, edited by S. Sonnentag. 